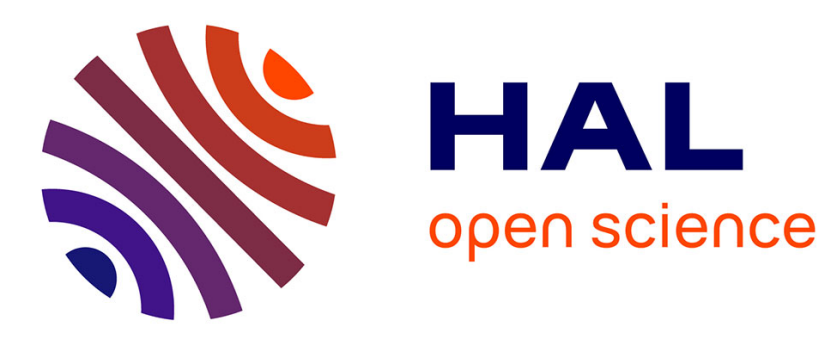

\title{
I Eat Therefore I Believe: The Raw Food Diet, a Believing Solution for Healing
}

\author{
Solenn Thircuir
}

\section{To cite this version:}

Solenn Thircuir. I Eat Therefore I Believe: The Raw Food Diet, a Believing Solution for Healing. The International Journal of Religion and Spirituality in Society, 2019, 9 (1), pp.41-55. 10.18848/21548633/CGP/v09i01/41-55 . hal-02143043

\section{HAL Id: hal-02143043 \\ https://hal.science/hal-02143043}

Submitted on 6 Jun 2019

HAL is a multi-disciplinary open access archive for the deposit and dissemination of scientific research documents, whether they are published or not. The documents may come from teaching and research institutions in France or abroad, or from public or private research centers.
L'archive ouverte pluridisciplinaire HAL, est destinée au dépôt et à la diffusion de documents scientifiques de niveau recherche, publiés ou non, émanant des établissements d'enseignement et de recherche français ou étrangers, des laboratoires publics ou privés. 
The International Journal of

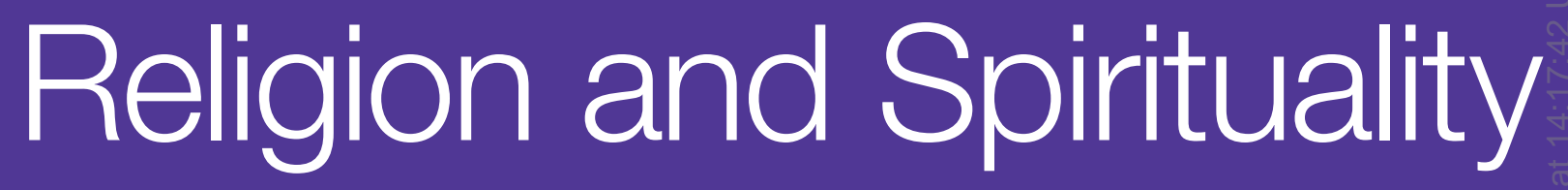
in Society

\section{Eat Therefore I Believe}

The Raw Food Diet, a Believing Solution for Healing 


\section{EDITOR}

Luis G. Roger-Castillo, University of Granada, Spain

HEAD OF JOURNAL PRODUCTION

McCall Macomber, Common Ground Research Networks, USA

\section{EDITORIAL ASSISTANT}

Crystal Lasky Robinson, Common Ground Research Networks, USA

\section{ADVISORY BOARD}

The Religion in Society Research Network recognizes the contribution of many in the evolution of the Research Network. The principal role of the Advisory Board has been, and is, to drive the overall intellectual direction of the Research Network. A full list of members can be found at https://religioninsociety.com/about/advisory-board.

\section{PEER REVIEW}

Articles published in The International Journal of Religion and Spirituality in Society are peer reviewed using a two-way anonymous peer review model. Reviewers are active participants of the Religion in Society Research Network or a thematically related Research Network. The publisher, editors, reviewers, and authors all agree upon the following standards of expected ethical behavior, which are based on the Committee on Publication Ethics (COPE) Codes of Conduct and Best Practice Guidelines. More information can be found at:

THE INTERNATIONAL JOURNAL OF RELIGION AND SPIRITUALITY IN SOCIETY https://religioninsociety.com

ISSN: 2154-8633 (Print)

ISSN: 2154-8641 (Online)

https://doi.org/10.18848/2154-8633/CGP (Journal)

First published by Common Ground Research Networks in 2019 University of Illinois Research Park

2001 South First Street, Suite 202

Champaign, IL 61820 USA

$\mathrm{Ph}:+1-217-328-0405$

https://cgnetworks.org

The International Journal of Religion and Spirituality in Society is a peer-reviewed, scholarly journal.

\section{COPYRIGHT}

(C) 2019 (individual papers), the author(s)

(C) 2019 (selection and editorial matter),

Common Ground Research Networks

\section{(이) $\odot \odot$}

Some Rights Reserved

Public Licensed Material: Available under the terms and conditions of the Creative Commons Attribution-NonCommercial-NoDerivatives 4.0 International Public License (CC BY-NC-ND 4.0). The use of this material is permitted for non-commercial use provided the creator(s) and publisher receive attribution. No derivatives of this version are permitted. Official terms of this public license apply as indicated here: https://creativecommons.org/licenses/by-nc-nd/4.0/legalcode

\section{Crossref}

https://religioninsociety.com/journal/model.

\section{ARTICLE SUBMISSION}

The International Journal of Religion and Spirituality in Society publishes quarterly (March, June, September, December). To find out more about the submission process, please visit https://religioninsociety.com/journal/call-for-papers.

\section{ABSTRACTING AND INDEXING}

For a full list of databases in which this journal is indexed, please visit https://religioninsociety.com/journal.

\section{RESEARCH NETWORK MEMBERSHIP}

Authors in The International Journal of Religion and Spirituality in Society are members of the Religion in Society Research Network or a thematically related Research Network. Members receive access to journal content. To find out more, visit

https://religioninsociety.com/about/become-a-member.

\section{SUBSCRIPTIONS}

The International Journal of Religion and Spirituality in Society is available in electronic and print formats. Subscribe to gain access to content from the current year and the entire backlist.

Contact us at support@cgnetworks.org.

\section{ORDERING}

Single articles and issues are available from the journal bookstore at https://cgscholar.com/bookstore.

\section{HYBRID OPEN ACCESS}

The International Journal of Religion and Spirituality in Society is Hybrid Open Access, meaning authors can choose to make their articles open access. This allows their work to reach an even wider audience, broadening the dissemination of their research. For more, please visit https://religioninsociety.com/journal/hybrid-open-access.

\section{DISCLAIMER}

The authors, editors, and publisher will not accept any legal responsibility for any errors or omissions that may have been made in this publication. The publisher makes no warranty, express or implied, with respect to the material contained herein. 


\title{
I Eat Therefore I Believe: The Raw Food Diet, a Believing Solution for Healing
}

\author{
Solenn Thircuir, ${ }^{1}$ PSL Research University, France
}

\begin{abstract}
As Alan Levinovitz argued, food can be an entry point into the study of religion. In this sense, how does religiosity manifest itself in the raw food diet? This food practice is based on the idea of finding salvation, but for this to happen, one must find its nature. The raw food leaders promise a revolutionary diet that could cure disease and guarantee the return to Adam and Eve's natural paradise. By condemning a cultural symbol such as cooking, they claim to have the key to escape the degenerative modernity. They seduce and convert a cult of followers in Western countries. The dichotomies on which the norms of this diet are based refer to the notions of the pure and the impure, of the good and the bad. They divide up the world according to moralistic binaries. This article aims to analyze the raw food diet values and how a myth is constructed by the updating of religious foundations where love for nature and believing in the power of certain foods can be considered as a religion.
\end{abstract}

Keywords: Food Practice, Nature, Religious Transformation, Secularization, Spirituality, Postmodernity

\section{Introduction}

$\mathrm{T}$

The development of new spiritual practices and movements aimed at fulfilling new individual aspirations is one of the aspects of the secularization process initiated from the Age of Enlightenment and a characteristic of postmodernity. The notion of spirituality emerged in the sixteenth century and was defined as "everything that relates to the life of the soul as opposed to the imperatives of the body" (Bisson 2012). ${ }^{2}$ Spirituality is thus an illustration of the religious world, but is not limited to its perimeter. The sociologist Bruno Etienne affirms that a secular spirituality exists today (Bisson 2012); like religions, it is characterized by the search for meaning, inner adventure, well-being, and personal development. A wide range of situations are inscribed in and involved with secular spirituality, including the act of believing, especially in forces, which has an influence on the daily lives of individuals. These forms of spirituality are found in a number of alternative health-related practices, such as raw foodism.

Indeed, the experiences of disease, through the wandering itineraries of individuals in search of relief and well-being, allow us to understand this call towards an analytical grid that institutional discourses would be powerless to fill. It is in this context of transition that raw foodism emerges. This food practice reveals an initiative of self transformation. This article aims to understand, with a sociological approach of religion, from the individual stories of fifty-seven raw foodists in France and the United States, how experimenting with a new way of eating makes possible other ways of living in one's environment and body. Raw foodism is a spirituality oriented toward personal accomplishment through the purification and the healing of the body.

Sixty-five semi-structured interviews of an average duration of 2.5 hours were conducted between 2014 and 2018 with individuals tending to eat exclusively raw food. The interviews took place in France (Paris, Marseille, Lyon, and their surrounding areas), as well as in the United States (California's San Francisco Bay area). The respondents consisted of twenty-six women and twenty-nine men between the ages of eighteen and eighty-two. Ten participants were reinterviewed during this period. The sample recruitment process was carried out on several fronts. Contact was made through social networks due to the existence of several online communities, as

\footnotetext{
${ }^{1}$ Corresponding Author: Solenn Thircuir, 2 rue de la Charité, Centre Norbert Elias, EHESS, PSL Research University, Marseille, Bouches-du-Rhone, 13002, France. email: Solenn.thircuir@ehess.fr

${ }^{2}$ Translated from French "tout ce qui touche à la vie de l'âme par opposition aux impératifs du corps."
} 
well as through events that required immersion in the community. Other interviews were conducted through "snowball" sampling (Atkinson and Flint 2001). They gave their consent to be interviewed and recorded for this study.

The first part of the article will focus on the foundations of the raw food ideology, which will then allow us to understand, in the second part, the elements which justify the commitment to the food practice by the respondents. Finally, we will show how the raw food phenomenon enables a greater reflection on the historical dynamics of secularization.

\section{The Raw Food Diet, a Poetics of Nature}

\section{A Romantic Reading of the Past}

Raw foodism is a food practice that emerged at the end of the nineteenth century in Europe. Thanks to new communication channels, it gained in popularity in North America and experienced a new boom during the last decade. This food practice is often associated with the work of Dr. Bircher-Benner (1867-1939) of Switzerland, who advised the exclusive consumption of fresh fruit and vegetables as well as seeds and nuts. Other physicians and scientists subsequently became interested in this diet, such as Dr. Paul Carton (1875-1947), Dr. Max Gerson (1881-1959) and biologist Jean Seignalet (1936-2003). A new development in raw foodism emerged in the United States, officially around Ann Wigmore, founder of the Hippocrates Health Institute, who used food as an alternative to surgical and chemotherapeutic breast cancer therapies. ${ }^{3}$ Vitality is dependent on the purification of the body (Lahlou 1999), while cooking represents the exit from a state of nature, and its abandonment would mean the regeneration of a denatured and artificial body. The body must first find "its nature" (Ouédraogo 1998). Raw foodism is neither a uniform practice nor a uniform philosophy, and presents various forms of food exclusion and food combinations that come under different worldviews. From this perspective, raw food is not only an alternative diet. Eating raw begins a dismantling of the symbolic: no transformation, no separation of outside and inside, no temporality, no time, and no history. Raw foodism creates a new world - a myth of creation.

The followers of this food practice reflect on the place of humans in nature and on the theorization of a state of nature. By questioning what characterizes humanity compared to other living beings, they believe that we should feed ourselves exclusively on foods as they are found in the environment. The main idea is that absorbing the energy of food puts the eater in relation with the nourishing power of nature that will manifest itself through ingestion. To be properly connected to the environment, products derived from it should be eaten without being processed. It is the image of nature that symbolically enters into oneself, with its order and its potential disorders.

From a holistic perspective, food is seen as the most important relationship of the human microcosm with the outside world, and its role is to maintain the internal balance of the body (Fischler 2010). The "right food" is the one that is able to maintain this balance. Nature hierarchizes and assigns a scale of values according to food: food intake is limited to a few inescapable rules delimiting the pure and the impure where nature defines impassable norms (Arppe, Mäkela, and Väänänen 2011). It becomes the frame of reference for normality and a socially constructed institution: it falls within the realm of laws, regular causalities that can be generalized. In this perspective, outer nature, like inner nature, are parts of the same continuum, an all-encompassing and transcendent whole. Pierre describes the current context as no longer following these laws, and society's distance from nature. Raw foodism would be, according to him, the way to find a lost harmony:

\footnotetext{
${ }^{3}$ http://hippocratesinst.org/the-institute/ann-wigmore-founder
} 
I became a representative, original being, immersed in a crazy world. Society has codified what is wrong, food, sexuality, etc. Few people have been able to benefit from such a particular context, close to human's nature. This touches on the absolute of original truth. Jesus, Buddha, they have attained enlightenment. It helped me understand what they might have said. I'm like uprooted, there's something dead inside of me. (Pierre, 52 years old, French)

Human nature is perceived as preceding the progress and techniques developed by humans. The return to nature, before anything else, is considered in the act of eating. In doing so, raw foodism glorifies a lost golden age. Alan Levinovitz (2015) argued that the myth of a lost paradise is a recurring belief within cultures and across generations that influences the relationship to food. Food practices are borrowed from these beliefs, and the magical thinking becomes an important part of the identity of eaters (Levinovitz 2015). He adds that the love of nature operates as a religion and that the division between artificial modernity and the natural and paradisiac past is a driving force for the development of these practices (2015). Thus, raw foodism has a romantic approach to the past based on an ideal and defines a utopia that should be found in the regeneration of the body.

\section{The Fear of Degeneration and Disease as Social Criticism}

Cooking is the art of transforming food and creating appetizing dishes from substances that would, for the most part, be difficult to consume and assimilate by the body before their modification by culinary operations. According to the raw food ideology, the chemical transformation by cooking is associated with a process of destruction of food by heat. The living substance would become toxic-some temperatures are likely to produce mutagenic and carcinogenic substances. The immune system would be activated by eating cooked food. Raw foodists are opposed to the idea that cooking constitutes a step forward among the successive adaptations and technical transformations of humans on their environment. On the contrary, it would have contributed to the artificialization of lifestyles by tearing people away from their true nature.

However raw foodism is not only a particular approach to cooking: from a biological perspective, according to the interviewees, human nature would have changed little during the Homo lineage. James, eighty-two years old and French, explains the role of instinct and how it can operate. According to him, the organism only recognizes and uses "natural foods" properly: "instinct would not work with food that does not exist in the environment." The gap between living conditions and changes in our diet would not only put our bodies to the test, but would prevent them from recognizing their needs and determining how we should meet them. Organisms lose their vitality by accumulating toxic substances through food intake and, more broadly, through lifestyle. Pathological processes would appear as natural responses implemented by the body to rebalance it, and adapt it to harmful influences, to heal it. The purification is of two orders: it is first of all about eliminating the toxic materials which are accumulated in the body, generated in an endogenous way as a normal part of the functioning of the metabolism, and exogenous, ingested and retained because of the incapacity of this one to face the eliminatory load. Then, it is a matter of metaphorically removing the weight of knowledge and ideas perceived as harmful, produced by society. The new approach to symptoms and the state of nature induces a re-reading of practices viewed as not natural, for example the use of medication is considered as an aberration.

Modern medicine provides a wrong approach of the body. It is based on the culinary paradigm and the adaptation of the body. (James, 82 years old, French) 
Although described by raw foodists as responses to an inadequate diagnosis, these practices appear as to deny the vital and self-repairing force of the body. These practices deprive the sick of their autonomy and, according to the raw foodists, they are deprivations of liberty. Banishing them is a first step in recognizing the body's ability to regain its balance. Allopathic medicine is portrayed as a desperate and illusory attempt to repair disorders, symptomatic of a society that artificializes life and that is fundamentally unnatural. These healing practices could in no way cure the body because, by suppressing the symptoms, they would divert us from the "real cause," preventing the body from performing its vital functions of purification, interrupting this process of repair. Nothing but the body itself could cure it. Leaving the body to its own fuctions and promoting the health conditions that allow it to devote all its vitality to healing are an act of devotion of body and mind. This commitment shows hope for a better future.

\section{The Promise of a Better Future}

Raw food ideology is based on an ideal of health. It manifests as a vision of a humanity relieved of suffering and disease. Its ambition is to make the individuals become "more alive." Echoing hygienist theories and other alternative therapies, it reverses the approach of modern medecine defining disease as the result of an external attack by a pathogen creating an alteration in the body. If health is a result of living conditions, raw foodists perceive disease not as a failure of individuals to adapt to the constraints of their environment to resist aggressions, but as a manifestation of the general maladjustment of the modern way of life to organisms. Indeed, in the absence of conditions that allow it, the body cannot experience full health, unlike wild animals that have preserved their instinct. These principles serve as laws and truth in the raw foodists' discourses. Health is therefore our natural state of being. The symptoms of the body should be interpreted as warning signs and a call for a profound change in lifestyle, starting with food.

Since a very young age, I was attracted by the laws of nature. I am aware that there's something that orders everything. There are rules in nature. (Jasmine, 43 years old, French)

Disease is not only preventable, it can be eradicated. Raw foodists thus refuse to consider disease as an inevitable event, a fatality, that should simply be prevented, because they believe that it has no reason to be unless we cause it, either by deficiencies, or by intoxication, or even by both.

Health and well-being can only be achieved when living conditions meet the emotional, physiological, and spiritual needs of the individual. The idea of an orderly and just life, accessible to all, attracts not only sick people, but also those aspiring to a better life. Raw foodism, by claiming to meet these needs through lifestyle transformation, provides explanations on how the body works in order to make people aware of the importance of such food reform. It is based on a liberating discourse through commitment in practice. By referring to a state of nature synonymous with freedom and protection, raw foodists evoke universal laws. The global understanding to which they claim is to banish fear. The purification of the body appears as a step in a spiritual realization of self. Happiness, the true one, is a sensitive experience linking body and mind in an encompassing whole. The purification of the body and, by extension, of the spirit, is a progression, and constitutes a liberation from a previous life.

Quitting smoking, quitting drinking, quitting drugs can be very hard, quitting cooked food is maybe harder for most people. For me it was a blessful experience. (Chase, 62, American)

The raw foodists, believing that modern lifestyles deny the conditions that have made life possible, describe a return to a Garden of Eden. According to them, the body follows laws 
described as vital principles. They refer to a force that the body possesses to regain its balance and health, its normal state. This commitment is therefore based on conviction and faith in the power of the living to establish a just order. Such an approach is illustrated by the idealization that raw foodists make of animal existence in nature based on instinct. Instinct is the tool by which well-being is made possible. Wild animals, which have preserved their instinct, flourish in an optimal way according to their environmental and genetic possibilities. However, the "natural" instinct is subject to ambiguity: taken as a state of nature, it is nevertheless the subject of learning. This guide, a priori innate, but forgotten because of the errors of human evolution and techniques, must be rediscovered. The upholding of this state, both natural, but on which, paradoxically, it is necessary to work, to keep a line of conduct, is a process of every moment. Mistakes that can be made are threats in this fragile balance, but the greater vitality, the better the body is able to cope with and eliminate toxic substances. The organism makes efforts to eliminate the toxic substances of which it is exposed. The promise of a better and happier future is based on abandoning a degenerating way of life. Self-healing is faith in the mechanisms of the body. Raw foodists are convinced that it is only by striving for healthy living that they can claim to achieve their greatest joys, experience peace of mind, and a happy connection with the world, which would be their birthright.

\section{Wandering Itineraries of Individuals in Search of Meaning}

One magical evening in 1984 my mind exploded. I was studying the Natural Hygiene Course, which was masterminded by Dr. T. C. Fry. Dr. Fry understood how to save and resurrect my life. I also understood what humanity needed to undo disease, suffering and its descent toward extinction. My revelation of health via the principles of natural raw food diet and self healing set in motion my rapid healing and lit a fire in me which is still raging on. From an abyss on the brink of destruction to the pinnacle of health, here I am! Some people describe my passion for getting people the messages of raw food eating and self healing as driven and indomitable. A minute has rarely gone by in twenty years when I have not been caught up in thinking of ways to effectively present this information so that everyone can understand and embrace it. Where is this passion coming from? From my desire to help others after recovering from eight years of my own hellacious suffering, my will to live in a healthy body and enjoy the fruits of life, and to see my fellow Earth beings realize the same. No one deserves to suffer! Anyone who knows me knows that I'll be educating the world for the next hundred years, or as long as it takes for humanity to wake up to healthful living. I love doing this workempowering people with this knowledge and seeing them overcome suffering, thwarting death, and becoming healthy and liberated from the medical traps is heartening and exhilarating! Every woman, man and child deserves to live a healthful life in a healthy body! The information describing how to heal, rejuvenate and regenerate is here and available to everyone now and it is high time that everyone gets it! As Thomas Henry Huxley said, "Education is the instruction of the intellect in the laws of Nature." Natural is the way to be! (Fry and Klein 2013, 4)

In his book, The Vibrant Diet, an American raw foodist, David Klein, summarizes the experience of this diet as an initiatory journey. The individuals I have met over the past three years have all brought to light a reflection around their personal problems in their relationship with their bodies and their existence. By telling their life stories, they highlight a process of subjectivation. 


\section{Conversion: A Dynamic Based on Disenchantment and Re-enchantment}

Respondents unanimously mention a "turning point" when they speak of their encounter with raw food ideology. This event appears as absolute and unifying for respondents who describe a before and an after in their life trajectory. This search for wellness must be analyzed to understand the magnitude of the impact of a discourse that supports the possibility of changing the course of things simply by changing the way of life, especially when no other discourse generates hope.

We're just people, everybody eats, everybody wants to be healthy, everybody wants to live their lives in the best possible way, and here I am! I discovered something that upset me, that changed me not only physically but also in my head. Because I was a very lonely person at home, I had raised my children, and suddenly this change in chemistry within me allowed me to discover who I really was, to want to really communicate, not to be afraid. (Kristie, 54 years old, French)

At the beginning I said it was a change of diet, I was told, "Yes you're on a diet," but for me it's very different; it's not temporary; I never wanted to go on a diet. And now I say, it's a life change. I don't have the same friends; I don't have the same place to live; well, everything actually moved, not the same job. (Fabrice, 50 years old, French)

If the turning point is an entry into a new way of being in the world, it does not appear to be a radical break with the individuals' previous life. Very often, the trigger is conditioned by the convergence of contextual elements that are favorable to it: the experience of the disease, a problematization of food, a questioning of institutionalized forms of knowledge, the imperative of personal realization, etc. leading individuals to question their own existence. Respondents have never accidently stumbled upon this type of diet, which is consistent with a number of their concerns: the search for a solution is a process of recollection of meaning. It is more about reappropriating existing elements than integrating new ones. This reappropriation of knowledge gives a personal meaning, as Céline testifies:

I became more and more interested in food through health, health through food. I first saw a video about we are what we eat, something like that, where there were raw foodists. I said to myself, but who are these raw eaters, I don't even want to think about it, I remember I watched it with my mother, we thought they are crazy, giving up cooked food, it's the thing that I could never do, because I've always loved to eat besides, I've always loved to cook. And at the same time it seemed logical to me because I remembered that I had actually asked myself the question, but long ago, about why we need to cook our food, it is strange to cook, like all the philosophical questions you ask yourself when you're young and people say stop asking yourself those questions, why and why and why, because that's the way it is. I had not continued this questioning and I had told myself that it is true that we hear all the time that cooking kills vitamins, kills minerals, we drink orange juice for vitamin $\mathrm{C}$, but at the same time the juice we buy is pasteurized, well it's not logical, so it's true that at the same time I told myself it's logical to eat raw. (Céline, 23 years old, French)

The sociologist Danièle Hervieu-Léger (2001, 93) distinguishes two movements in the context of this spirituality of being oneself: "conversionist movements" are radical new entries which provoke an emotional experience inducing an immediate change of life in individuals; and "movements of spiritual rationalization" referring to work on oneself, in search of selfimprovement. However, the author acknowledges the porosity of these movements. The personal 
experiences of the respondents mix their characteristics, which are an integral part of the conversion experience. The moment of conversion, of adherence to raw foodism, and as the first step in entering into practice, is often marked by the meaning given to suffering experienced. This is why the experience of disease is often present in the retrospective discourse of respondents who make it one of the motivations in their search for a solution. Here, healing is presented as inseparable from spiritual deliverance. It involves accepting physical suffering, which is characterized by what respondents define as "detoxification" and purification.

I have the feeling, it is my belief, that we are forced to go through this whole period when horrible things happen. I have the feeling that Adam and Eve were perfect, and everything was perfect but they did not know it, and they could not know it, and to know it they needed to experience the opposite of what is perfect. And I have the feeling that we are experiencing all of this, all these millennia, all this history to gradually return to the Garden of Eden, but we really need to make all these mistakes to really understand and assimilate them, and to understand that in reality we are perfect. (Lily, 30 years old, French)

The idea of hardship underlying and associated with the mistakes committed in human history, in their attempt to transform nature, maintains punitive representations of disease and the evils of society which are all markers of the cultural roots of Christianity and magical thought. (Champion 2000b). The return to health involves questioning and transforming habits and lifestyles that are symbolically recognized as the mark of individuals' past mistakes. The healing of all evils is no longer extramundane, as is the case in the religions of salvation. Freed from their heavy toxins, freed from what they consider to be the psychological and somatic miasmas of their former existence, they speak of their body with the joy of no longer suffering from it, and finally choosing it and modelling it. By integrating salvation into the here and now, individuals mobilize themselves in the service of healing their own bodies and regeneration that is now accessible to all. The discovery of this food practice, and the reinterpretation of the respondents' past in the light of this new experience gives meaning to the suffering experienced. The raw foodists' experience highlights the process of disenchantment that Max Weber uses to describe the devaluation of religion and the secularized society (Weber 1993). Alongside that of disenchantment, there is a process of re-enchantment that shows an array of opposing tendencies. As Richard Jenkins $(2000,18)$ says, "Disenchantment has indeed been the fate of the world, but this has only served to open up new vistas of possible (re)enchantment."

\section{A Search for Unification of Identity: Raw Foodism as Spiritual Self-Realization}

In raw food practice, the management of the body is spiritualized. It incorporates both traditional religious representations of healing as a sign of salvation and expectations to connect all facets of the person in order to claim the spiritual self-realization. Through their stories, individuals refer to the idea of an essential awareness to restore harmony in the world. If the entry into the food practice announces the transition to a new system of norms, involving the body, which acts as a model in public space, it also manifests the reorganization of the trajectories of lived trials in spiritual terms. In the continuity of their personal identity, this event allows individuals to constitute themselves as subjects of their own history, creating a subjective feeling of reconciliation with themselves (Hervieu-Léger 2001). Indeed, the experience of the world described by the respondents translates a disenchanted and unsatisfactory life trajectory toward the promise of a better existence. Darrin, 78 years old and a French retiree, describes how he felt prior to starting the raw food diet: "I was alone and sad at the beginning." He then explains how the food practice was accompanied by a reflection on the social dimension of the act of eating. This social dimension would prevent one from choosing the diet one wants. He shows how this 
awareness "then... became a natural act, with pleasure and joy. I realize that we ate for the group and not for ourselves." He shows that his awareness has freed him from this constraint.

The performative dimension of the purification of the body can be ascetic and translates the injunction to a concern for oneself. Individuals become responsible for their existence in all aspects of their lives. The disenchantment of the world as presented by Max Weber (2010) is one of the consequences of the secularization and desacralization of the world. It marks the rise of dissatisfaction among individuals. The experience of raw foodism is pragmatic. Before being religious action, it is the solution found to respond to the problems felt as such by individuals, particularly around health issues. Medical institutions are perceived as powerless to meet their expectations, particularly through the medicalization of their lives, which costs them their autonomy (Illich 1975).

Conversion gives rise to the development of commandments from which individuals make their assembly of meaning. The technical, social and cultural dimensions, as well as the individual's capacity for personal mobilization, participate in the attainment of the goal of selfrealization. This mobilization, from which a profound reform of the way of life becomes possible, is only possible on the basis of a strong and transcendent conviction that the body can find its truth through its regeneration, creating a need and a duty of fulfilment in the world and for living an harmonious life.

\section{Announcing the Good News}

The conviction of the individuals who experience raw foodism often leads them to put themselves in the position of proselytes in order to bear witness to the world by spreading the good news to family and friends, running a blog, creating an online video channel, interviewing people, becoming a coach, starting a wellness business, becoming a raw food chef, creating recipes, selling food products, writing a book or an article to testify. These are the trajectories chosen by the majority of interviewees. The self-testimony questions the interiorization, the intimate analysis, and the personal narrative of the respondents. The spiritual fulfillment of the individual is realized notably in its participation in the transformation of the world of which he or she is convinced is necessary. This work of dissemination is a manifestation of a duty. This is the case for Laura who in 2015 undertook a tour of France with her companion to go to meet the people who practice raw foodism in order to inspire others through the transmission of these testimonies. The proselyte approach of which she gives feedbacks also attests to the incomprehension and the gap with their relatives:

Anyway I think the reactions are proportionate to how you [talk about it], at first I was so hard new converted that the reactions were proportional to it, because I really thought, everyone was going to start eating raw around me, I was going to give them the information and they were going to say, "Wow, that's great, the girl found the solution to all our problems," and it does not work that way. Because everyone has to make their own trajectory... and it doesn't happen at the same time for everyone....[I]t's exciting because it's so miraculous, nobody believes it, it seems that no one believes that food has an influence on health while it still makes sense that what you put in your body can have an impact. But no one seems to believe it because it would be too easy. "Just eat fruit and vegetables" seems too easy, well yes! I met 50 people who healed just last year, and yes it works. That's what we learned too, we can't convert the whole Earth, you see, of course it moved our relatives, they started to ask questions, to change things. But you can talk to guys for hours, you can even give them a try, if they don't want to [they won't change] (Laura, 27 years old, French)

Respondents base their engagement on their direct experience in the world. The test of credibility of their person is therefore very strong. Their mission of transmission can also take the 
form of exemplarity, which is similar to passive militant action, that is, the individuals do not explicitly try to convince the others by providing arguments: this strategy is all the more effective in attracting sympathizers as the credit given to experiential knowledge is valued by individuals. They tend to embody, in the purest way possible, the new norms and values of practice.

I wanted to convince everyone. Now I know that you have to convince by what you inspire, first you have to do it yourself and then they will come to you, it's not up to you to tell them. In general you always have to embody what you want to promote and then it's the people who will ask you for advice. I have friends who ask me for advice and eat more fruit than before. If I had forced them to eat more fruit it wouldn't have worked. (Mathieu, 22 years old, French)

Proselytism is an integral part of the dynamics of raw foodism. Like any social movement, it is initiated by personalities who embody the role of mentors. According to Danielle HervieuLéger (2001, 94), the mentor is "supposed to act as a guide and a companion, a privileged witness of the journey that the individual makes at his own pace, according to the progress of consciousness he makes." 4 Quite often, the mentor embodies the new norms to which the followers conform. He is a moral entrepreneur and appears to be playing an essential role in the spread of the ideology, as well as in its perpetuation over time. The moral entrepreneur, in the sense of S. Scheerer (1985), is the central actor of movements that tend toward the creation of norms and values. Howard S. Becker (1985) distinguishes two types of moral entrepreneurs: those who create the norms and those who enforce them. The norm maker is associated with a traditional norm reformer, which he considers unsatisfactory and inadequate. This type of entrepreneur feels invested with a humanitarian mission: "The one who participates in these crusades is not only concerned with getting others to behave 'well,' according to his appreciation. He believes it is good for them to 'behave well'" (Becker 1985, 172). ${ }^{5}$ The mentors of raw foodism seek above all to awaken moral needs by trying to increase the general awareness of what they consider to be disorders of the social order by explicitly pointing out the causes, alerting the public to dangers, as well as by presenting the virtues of a reform of the way of life. Before being inventors of practices and founders of institutions, these personalities are creators of theories. They do not set a standard that should be imposed, including against resistance from society; they rather rely on the process of this phenomenon. They seek to "modify the social representations associated with a particular practice or consumer good" by identifying the social causes of a phenomenon considered undesirable and by developing "symbolic engineering" (Fassin and Memmi 2004, 55). ${ }^{6}$

\section{Bringing Utopia to Life by the Group}

The arrival in a new state of life gives rise to a need of belonging to a community. The "militant utopian group," to use Danièle Hervieu-Léger's $(2001,167)$ words, participates in the socialization of individuals at the same time as the dissemination of the practice. These spaces of socialization allow for the experimentation with individual subjectivities and a reciprocal confirmation. The establishment of a militant group is an attempt to make the world intelligible by structuring it. The weak institutionalization of raw foodism and the increasing use of social networks in the development of new ways of life, makes social networks essential spaces for the

\footnotetext{
${ }^{4}$ Translated from French: "supposé agir comme un guide et un accompagnateur, témoin privilégié du parcours que l'individu effectue à son rythme, en fonction des progrès de conscience qu'il accomplit."

${ }^{5}$ Translated from French: "Celui qui participe à ces croisades n'a pas seulement le souci d'amener les autres à se conduire 'bien,' selon son appréciation. Il croit qu'il est bon pour eux de 'bien' se conduire."

${ }^{6}$ Translated from French: "modifier les représentations sociales associées à telle ou telle pratique ou bien de consommation en identifiant les causes sociales d'un phénomène jugé indésirable et en développant 'une ingénierie symbolique."”
} 
existence of such movements. The sociality of Web 2.0, characterized by omnipresent and instantaneous interactions, forces us to "rethink the dimensions of social life by widening its architecture beyond the limits of human relations and public spaces" (Di Felice and Hugon 2004, $5){ }^{7}$ Raw food online communities bear witness, beyond their content, to the emergence of a new form of sociality marked by the simultaneous connection of spaces, digital networks, data, information, and people. This form of digital activism generates an overcoming of the architecture through which the social has been constructed and designed (2004). The social network creates a degree of co-presence between people separated by distance. It recreates "being together," allowing users to share each other's experiences and to exchange simultaneous expressions of emotional and moral support underlying a need to reassure themselves about their beliefs.

Having that resource to make me think that's what I want, and there are people who are in the same process, who can give me advice and from whom I can draw inspiration and perhaps inspire as well. Because we need people who are a bit like us, to be with people all the time, not making you feel [like] the different and weird person, the marginal one, it's tiring. It's tiring because you're never actually completely comfortable. And when you're with people who are like you, you're much more comfortable being yourself. So that's it, so I'd like to meet many more. (Céline, 23 years old, French)

The militant group thus ensures the perpetuation of the practice and its expansion by recruiting new followers. The spaces in which militant groups operate appear as forms of esoteric mediation. The deterritorialization and immaterial character of these spaces makes it possible to build spiritual communities where individuals can convey their ideology and create an interconnected world. The use of the internet illustrates the "culture of the self" in Michel Foucault's (1997) sense, as a social practice. If in the past the mentors were mainly philosophers and religious personalities, the new modes of information and communication have profoundly transformed these modalities. Online, individuals expose the state of their soul, seek advice, and provide it in a dynamic where everyone can play the role of a preceptor who updates his representations: we notice here a work of communication with others, an activity of speech and writing around self-care (Dreyfus and Rabinow 1984). Within this space, users can play the role of thought leader, guide, and companion. Thus, taking care of oneself involves a third party who plays a role in this process. Before being recognized for his skills and knowledge, the confrontation of another person generates confidence which gives him legitimacy. The challenge produced by the mentors and the capacity of social networks is to create new expectations. These spaces occupy an increasing place in individual and collective practices and makes this search of meaning generalized to all existences.

\section{Raw Foodism, or How to Rethink the Dynamics of Postmodernity}

\section{A Manifestation of Subject Formation in the World}

The analysis of raw foodism enables us to reflect on the relationship between individuals and society. Deep changes, initiated in the eighteenth century by modernity, transform individual's ways of being in the world and the model of society and characterize a new cycle in the history of the western countries (Lambert 2000). These changes also manifest themselves in the collapse of modern myths: the infinite expansion of the world (Lambert 2005), along with new environmental challenges and the naturalization of the idea of human progress. Both appear as a bearer of hope and a generator of anxiety. Human progress is no longer necessarily synonymous

\footnotetext{
${ }^{7}$ Translated from French: "repenser les dimensions de la vie sociale en élargissant son architecture au-delà des limites des relations humaines et des espaces publics."
} 
with general progress. Indeed, this postmodern period is characterized by a desacralization and de-utopization of history (Hervieu-Léger 2001). However, it is not synonymous with a loss of meaning in the future since individuals are invested at a personal level. The modern narrative of individualism has increased self-responsibility (Elias 2001). Today, we are witnessing the end of the grand narratives and the emergence of a new narrative: the search for meaning in existence is now invested at the individual level (Lyotard 1984). Realizing oneself as an individual illustrates a historical dynamic that tends toward individualism. The fragmentation of the identity of individuals underlines a period of crisis of the individual (Balutet 2016). According to sociologist Alain Ehrenberg (2000), these ways of elaborating personal commandments are attempts to define the individual. Everyone must find their truth. In doing so, new movements and practices arise from these expectations of achievement that other institutionalized forms would be impotent to fulfill.

Today's injunction to eat healthy results in the development of eating practices that carry strong identity elements. Although food practices are less influenced by religious traditions, due to the secularization of Western societies, they appear as recompositions of new religious actions. This position is shared by Alan Levinowitz for whom the discourses on food, whether scientific or not, use a religious and moral vocabulary, referring to great dichotomies $(\mathrm{good} / \mathrm{bad}$, natural/non-natural, pure/impure), prohibitions and sins (Levinovitz 2015).

\section{The Emergence of Multiple Spiritual Forms}

The decline of established religion is illustrated by the erosion of its practice and the societal sense of belonging to the same community of followers (Camus and Poulain 2009). According to Dutch philosopher and historian Woulter Hanegraaff (1999), this decline emerges from the loss of the centrality of the Christian religion as the bearer of collective symbolic foundations within the West. If the process is quasi-linear with the erasure of the religious in the years 1960-1970 (Bisson 2012), the context of secularization favors its recomposition: the multiplicity of spiritual forms responds to the decline of the great religious systems.

The disenchantment linked to the end of grand narratives and modern myths generates a renewed quest for meaning (Bisson 2012). Indeed, religious traditions have the role of "repositioning the individual in an ordered cosmos (prophetic history, sacred geography), and relinking him to a community of shared meaning (tradition)" (2012). ${ }^{8}$ Spirituality is therefore an indicator of contemporary changes in religious life. Its definition being broad, it encompasses both a multitude of movements at the same time as it envisages the fluidity of commitments (2012). It captures the development of multiple narratives in the postmodern context. Indeed, the new modalities of the relationship to transcendence are manifested by the phenomenon of individualization of belief and subjectivization of experiences. Religions carry symbols, and if these remain alive at the same time as secularization and individualization of society, this context makes it possible for individual appropriation, thus constituting new forms of spirituality. Faced with the decline of the established religion, the "New Religious Movements" emerged in the 1960s and were similar to counter-cultures. They contributed to the birth of the "mystico-esoteric nebula" based on a monistic conception of the world and an intramundanized version of salvation (Champion 2000a; Hervieu-Léger 2001): each individual aspires to their own spiritual realization and to an improved quality of life. The holistic position of the mystic-esoteric nebula decompartmentalizes the different worlds of knowledge - mixing science, ecology, religion, and esoteric popular practices (Camus and Poulain 2009) - as well as scales, distancing itself from Christianity and taking inspiration from religions throughout the world (Jeffrey 1998). The mystic-esoteric nebula is a religiosity centered on the individual. Its heteronomy symbolizes the profound upheaval of spirituality through modernity and the emphasis on personal fulfilment.

\footnotetext{
${ }^{8}$ Translated from French: "re-situer l'individu dans un cosmos ordonné (histoire prophétique, géographie sacrée), et de le re-lier à une communauté de sens partagé (tradition)."
} 
Raw foodism is one of these movements and is one of the manifestations of religious recompositions. Its ambition is to rebuild an alternative and harmonious world. It illustrates the processes of modernization and secularization formed by a set of spiritualities and beliefs that are heterogeneous recombinations of individual manipulations of religious and non-religious symbolic systems of various origins. Raw food ideology, however, remains affected by Christian values. Yet, the announcement of an extramundane salvation does not respond, or no longer responds, to the expectations of these individuals (Hervieu-Léger 2001). This is one of the main differences with the major religious groups. The individualized dimension of spiritual experience that leads individuals to think of themselves as beings endowed with interiority also leads them to no longer feel influenced by the will of a God. On the contrary, individuals consider themselves delivered from the tyranny of dogmatic religious structures that would hinder the discovery of the divine that resides in each of them.

\section{The Development of a Spirituality “Being Oneself” as a Search for Identity}

The study of raw foodism shows the individual scale of a historical moment. It also illustrates the end of the grand narratives of religious salvation, while participating in the foundation of another form of narrative: that of regeneration forcing the individual to produce their own salvation to overcome the feeling of incompleteness. In such a context, it is not surprising to note that personal dissatisfactions can be experienced as failures and that the call for re-enchantment is no longer guaranteed by traditional institutions in their symbolic dimension. These alternative practices bring new forms of narratives, hope of regeneration and harmony, based on a spirituality that seeks to reconcile humans with nature and was conceived as an inclusive totality in which humans have their place and are no longer seen as a negative bearer for themselves and for others. They are part of an alternative approach while participating in cultural norms of the postmodern period. Belief is individualized and justifies the dissemination of practices (HervieuLéger 2001). This dissemination "bears witness to the imperative that individuals must now provide themselves with the resources they need to develop meanings that correspond to their aspirations and experiences" $(2001,96) .^{9}$

The fracture of this historical period at the individual level is illustrated through the phenomenon of conversion, which presents a paradigm shift and an ontological quest. The development of multiple spiritualities in the postmodern context and the strengthening of selfconsciousness, consumerism, disillusionment with institutions, and a search for well-being have given rise to a spirituality market (Roof 2003). New forms of spirituality address dissatisfactions and re-enchant the world. The events that affect individuals refer to a global unhappiness from which they must purify themselves. Nevertheless, the loss of the institutional monopoly of truth regimes reveals contemporary spiritualities with affinities to the need of self-realization: Western conceptions of self-realization as a figure of a human and liberal religion prevail. They are based on the dream of a reunification between body and mind, between a healthy body and a finally happy existence in total fulfillment. It thus provides the language and explanations that enable individuals to express their aspiration and name their suffering and hardships. Raw foodism thus combines several variants of religious belief and action, illustrating spiritual recomposition in the context of secularization.

This is why raw foodism can be considered as a spiritual realization of oneself by advocating access to a regenerated life. Aiming for regeneration relays the hope of founding a new world. Deeply modern in its form, the raw food movement operates a double movement, between rejection of modernity and its affinity with the beliefs and modern culture of the individual (Hervieu-Léger 2001). The theme of regeneration participates in the construction of the belief of

\footnotetext{
${ }^{9}$ Translated from French: "témoigne de l'impératif qui s'impose désormais aux individus de se procurer par eux-mêmes les ressources indispensables à l'élaboration des significations qui correspondent à leurs aspirations et à leurs expériences."
} 
individuals, as a quest to escape suffering and disease, a quest that is not new, as Hervieu-Léger (2001) emphasizes, the mortal condition of the individual and protection against disease being central in forms of magic and religions. Practices such as raw foodism, although radical, cannot only be considered anti-discourse. They participate in the creation of a grand new narrative about self-fulfilment.

\section{Conclusion}

The unity between the human world and the divine dimension, the will to transform society but also the search for communalization are facets of postmodernity. Indeed, the demands of raw foodism, which envisages individual awareness as a vector of societal change integrating values relating to the body, the environment, education, spirituality, or politics, joins a generalized tendency which belives that a global change must first come from the individual. This is because the purification of personal lifestyle is associated with the solution to social problems (Dupuis 2015). As Melanie Dupuis $(2015,101)$, who studies the history of vegetarianism in the United States, says, "romance is embedded, once again, in a troublesome politics of purity that makes romantic visions of ideal diets the solution to larger, more complex social problems. This dietary reform conversation, once again, turns larger questions of social and political inequality into a problem of self-discipline."

Raw foodism is part of a constellation of other alternative practices and movements, including new techniques of personal development, Western and Eastern esotericism, an effective interest expressed in different references including, but not limited to everything about a "return to nature," raw foodism refers to values that are largely integrated with the rest of society. The romantic re-embrace of nature here involves a re-embrace of the past, which points out an issue concerning the separation of humans from their food production. Transforming the way we eat can be considered as attempts to repair our relationship with it and thereby overcome our broken system (Dupuis 2015).

The healing of the body in raw foodism represents a necessary reform of the way of life, based on the critical questioning of previous eating habits, sometimes despite the prognosis and/or prescriptions of official medicine. Previous habits and certain knowledge are then rejected due to the mistakes of modern industrial civilization and humans' progress. The raw foodist commitment is above all a choice which is integrated into the individuals' reality. Raw foodism is also the objectivization of a pure and virgin nature that would establish a just order, and a projection of oneself outside a society perceived as carrying elements harmful to health and the environment. The analysis of the interviews conducted during this thesis shows how common the vibrations are between the individual and the collective problems at the level of society. 


\section{REFERENCES}

Arppe, Tiina, Johanna Mäkelä, and Virpi Väänänen. 2011. "Living Food Diet and Veganism: Individual vs Collective Boundaries of the Forbidden." Social Science Information 50 (2): 275-97. https://doi.org/10.1177/0539018410396618.

Atkinson, Rowland, and John Flint. 2001. "Accessing Hidden and Hard-to-reach Populations: Snowball Research Strategies." Social Research Update 33 (Summer). http://sru.soc.surrey.ac.uk/SRU33.PDF.

Balutet, Nicolas. 2016. "Du postmodernisme au post-humanisme: présent et futur du concept d'hybridité" [From Postmodernism to Post-humanism: Present and Future of the Concept of Hybridity]. Babel 33: 19-47. https://doi.org/10.4000/babel.4391.

Becker, Howard S. 1985. Outsiders, études de sociologie de la déviance [Outsiders: Studies in the Sociology of Deviance]. Paris: Métailié.

Bisson, David. 2012. "La spiritualité au miroir de l'ultramodernité" [Spirituality in the mirror of Ultramodernity]. Amenis [Online] 11 (September). https://doi.org/10.4000/amnis.1728.

Camus, Sandra, and Max Poulain. 2009. "La place de la spiritualité dans la consommation : exploration et mesures dans les magasins d'alimentation biologique" [The Place of Spirituality in Consumption: Exploration and Measurement in Organic Food Stores]. Paper presented at the 12ème Colloque Association Etienne Thil [12th Association Etienne Thil Seminar], Institut de Gestion La Rochelle, France, October 8-9, 2009. https://www.association-etienne-thil.com/wp-content/uploads/2018/01/2009-

Camus_Poulain.pdf.

Champion, Françoise. 2000a. "Thérapies et nouvelles spiritualités" [Therapies and $\mathrm{Ne}$ Spiritualities]. Sciences Humaines [Social Science] 106 (6): 32-35. https://www.cairn.info/magazine-sciences-humaines-2000-6-page-26.htm.

2000b. "La religion à l'épreuve des Nouveaux Mouvements Religieux" [Religion as a test of New Social Movements]. Ethnologie française [French Ethnography] 30 (4): 525-33. http://www.jstor.org/stable/40991507

Di Felice, Massimo, and Hugon, Stéphane Hugon. 2014. "Introduction. Une socialité sans le social" [A Sociality without Social]. Sociétés [Societies] 124 (2): 5-6. https://doi.org/10.3917/soc.124.0005.

Dreyfus, Hubert, and Paul Rabinow. 1984. Michel Foucault un parcours philosophique. Au-delà de l'objectivité et de la subjectivité [Michel Foucault, a Philosophical Journey. Beyond Objectivity and Subjectivity] Paris: Gallimard.

Dupuis, Melanie. 2015. Dangerous Digestion: The Politics of American Dietary Advice. California Studies in Food Culture. Oakland: University of California Press.

Ehrenberg, Alain. 2000. La fatigue d'être soi. Depression et société [Weariness of the Self: Diagnosing the History of Depression in the Contemporary Age]. Paris: Odile Jacob.

Elias, Norbert. 2001. The Society of Individuals. Reissue. New York: Continuum International Publishing Group Ltd.

Fassin, Didier, and Dominique Memmi. 2004. Le gouvernement des corps [The Government of Bodies]. Paris: EHESS.

Fischler, Claude. 2010. L'Homnivore. Le goût, la cuisine, le corps [The Omnivore. Taste, Cooking, the Body]. Paris: Odile Jacob.

Foucault, Michel, 1997. Histoire de la sexualité III. Le souci de soi. [The History of Sexuality. The Care of Self] Paris: Gallimard.

Fry, T.C. and David Klein. 2014. The Vibrant Diet. The Timeless Guide to Vibrant Health via Our Natural Biological Diet. Paia, HI: Vibrant Health \& Wealth Publication.

Hanegraaff, Wouter J. 1999. "New Age Spiritualities as Secular Religion: a Historian's Perspective." Social $\quad$ Compass $46 \quad$ (2): $\quad 145-60$. https://doi.org/10.1177/003776899046002004. 
Hervieu-Léger, Danièle. 2001. La religion en miettes ou la question des sectes [Religion in Pieces or the Question of Sects]. Essai Société. Paris: Calmann-Lévy.

Illich, Ivan. 1975. Némésis médicale. L'expropriation de la santé [Medical Nemesis: The Expropriation of Health]. Paris: Editions du seuil.

Jeffrey, Denis. 1998. Jouissance du sacré. Religion et postmodernité [Enjoyment of the Sacred. Religion and Postmodernity]. Paris: Armand Colin.

Jenkins, Richard. 2000. "Disenchantment, Enchantment and Re-Enchantment: Max Weber at the Millennium.” Max Weber Studies 1 (1): 11-32. https://www.jstor.org/stable/24579711.

Lahlou, Saadi. 1999. "Des aliments tu feras médecine: Hippocrate revisité" [From Food you will Make Medicine: Hippocrates Revisited]. Cahier de Nutrition et de Diététique [Journal of Nutrition and Dietetics] 34 (2): 108-13. http://eprints.lse.ac.uk/29138/1/ Des_aliments_tu_feras_medecine_Hippocrate_revisite_\%28LSE_RO\%29.pdf.

Lambert, Yves. 2000. "Religion, modernité, ultramodernité : une analyse en terme de 'tournant axial"” [Religion, Modernity, Ultramodernity: an Analysis in Terms of "Axial Turn"]. Archives de sciences sociales des religions [Social Science Archives of Religion] 109 (March): 87-116. http://doi.org/10.4000/assr.20178.

. 2005. "Gérard Bronner. L'empire des croyances" [Gerard Bronner. The Empire of Beliefs]. Archives de Sciences Sociales des Religions [Social Science Archives of Religion] 130 (April-June): 113-202. http://journals.openedition.org/assr/2407.

Levinovitz, Alan. 2015. The Gluten Lie. And Other Myths about What You Eat. New York: Regan Arts.

Lyotard, Jean-François. 1984. The Postmodern Condition. A Report on Knowledge. Manchester, UK: Manchester University Press.

Ouédraogo, Arouna. 1998. "Assainir la société. Les enjeux du végétarisme" [Cleaning up Society. The Challenges of Vegetarianism]. Un corps pur [A Pure Body] 31 (September): 59-76. https://doi.org/10.4000/terrain.3138.

Roof, Wade Clark. 2003. "Religion and Spirituality. Toward an Integrated Analysis". In Handbook of the Sociology of Religion, edited by [Editor Name(s)], 137-48. Cambridge: Cambridge University Press. https://doi.org/10.1353/sof.2005.0059.

Scheerer, Sébastian. 1985. "L'entrepreneur moral atypique" [The Atypical Moral Entrepreneur]. Déviance et Société [Deviance and Society] 9 (3): 267-89.

Weber, Max. 2010. L'Ethique protestante et l'esprit du capitalisme [Protestant Ethic and the Spirit of Capitalism]. Paris: Agora.

1993. The Sociology of Religion. Boston: Beacon Press.

\section{ABOUT THE AUTHOR}

Solenn Thircuir: PhD Candidate, Centre Norbert Elias, School for Advanced Studies in the Social Sciences (EHESS), PSL Research University, Paris, Ile-de-France, France 


\section{The International Journal of Religion and}

Spirituality in Society aims to create an intellectual frame of reference for the academic study of religion and spirituality and to create an interdisciplinary conversation on the role of religion and spirituality in society. It is intended as a place for critical engagement, examination, and experimentation of ideas that connect religious philosophies to their contexts throughout history in the world, places of worship, on the streets, and in communities. The journal addresses the need for critical discussion on religious issues-specifically as they are situated in the present-day contexts of ethics, warfare, politics, anthropology, sociology, education, leadership, artistic engagement, and the dissonance or resonance between religious tradition and modern trends.
Articles published in the journal range from the expansive and philosophical to finely grained analysis based on deep familiarity and understanding of a particular area of religious knowledge. They bring into dialogue philosophers, theologians, policymakers, and educators, to name a few of the stakeholders in this conversation.

The International Journal of Religion and Spirituality in Society is a peer-reviewed, scholarly journal. 